\title{
1. Religion in international relations: Theory and practice
}

\author{
Jeffrey Haynes
}

\begin{abstract}
Attempts to salvage the secularisation model have interpreted evidence of burgeoning religiosity in many contemporary political events to mean that we are witnessing merely a fundamentalist, antimodernist backlash against science, industrialization, and liberal Western values ... Religious fervour is often dismissed as ethnic hostility ... typically explained away as an isolated exception to unremitting trends of secularization and seldom recognized as part of a larger global phenomenon. (Sahliyeh 1990: 19)
\end{abstract}

The quote from Sahliyeh emphasises that when the impact of religion on international relations (IR) is considered, it is often seen in relation to various normatively 'anti-modern' conceptions, such as 'religious fundamentalism' and 'ethnic hostility'. Yet to restrict an understanding of religious actors in IR to such a view means that we miss others whose concerns might be quite different.

Thinking about the most significant current issues in IR, it is impossible to ignore various manifestations of religious involvement. For example, over the last four decades, the IsraelPalestine conflict has increasingly been couched in polarised religious terms. Four decades ago, the Iranian revolution (1978-79) explosively focused world attention on revolutionary religious actors. During the 1970s, 1980s and 1990s, the Roman Catholic Church played a leading role in encouraging democratic transitions in various parts of the world, including Southern Europe, Latin America, Eastern Europe, Sub-Saharan Africa and East Asia. Most recently, 11 September 2001 ('9/11' New York and Pentagon attacks), 11 March 2003 ('3/11' Madrid bombings) and 7 July 2005 ('7/7' London bombings) were a connected series of outrage carried out by Islamist terrorists against governments and populations in the United States (USA), Spain and Britain. In addition, various religious actors for decades have taken the view that involvement in politics is essential as a part of their ethics. For example, there were religious groups involved in the Abolitionist anti-slavery movement in the nineteenth century, the civil rights struggle in the USA in the 1960s and 1970s, and the anti-apartheid movement in relation to South Africa. There were also prominent individuals - including Archbishop Desmond Tutu, Pope John Paul II and Archbishop Oscar Romero - who were of seminal importance for political outcomes in various countries in the recent past.

We can note two general categories of religious actors active today in IR:

- state actors (that is, governments); and

- non-state actors.

State actors are the governments of the world's nearly 200 states. While the great majority are secular in orientation, a few - including the governments of India, Iran, Israel, Saudi Arabia, and the USA - have foreign policies influenced by religious concerns. The perception in all cases is that domestic religious actors have an input into foreign policy, reflecting more gen- 
erally an interest in the association between material concerns - 'national security' - and the realm of ideas (norms and values). As Hay (2002: 194) notes:

ideas often hold the key to unlock political dynamics - as change in policy is often preceded by changes in the ideas informing policy and as the ability to orchestrate shifts in societal preferences may play a crucial role in quickening the pace, altering the trajectory or raising the stakes of institutional reform. ${ }^{1}$

There are in addition three main kinds of religious non-state actors - individuals, movements and institutions. Among religious individuals we can note various figures, including those already mentioned (Desmond Tutu, Pope John Paul II, Oscar Romero), as well as Osama bin Laden and the Dalai Lama. There are also numerous transnational religious movements, including al Qaeda, the Islamic State, the Muslim Brotherhood and the Evangelical Alliance. Finally, there are transnational religious institutions, including the Holy See/Vatican and, more generally, the Roman Catholic Church.

While the concerns and goals of such actors undoubtedly differ, what they have in common are the ability and inclination to act in IR in order to pursue their goals. For example, 'moderate' and 'extremist' Islamic groups, the Roman Catholic Church, Protestant churches, Hindu nationalists and Jewish fundamentalists all influence IR outcomes in a number of ways. Collectively they are influential because they inaugurate, embed and develop interactions with like-minded groups, often across state borders. Typically, such groups engage in transmission and receipt of inter-personal and inter-group exchanges of information, ideas, money and/or personnel. This is made possible by the fact that such religious actors inhabit a 'globalising social reality', characteristic of globalisation. This is an environment where previously significant barriers to communication have considerably diminished or even disappeared altogether. These circumstances serve to facilitate national, regional, continental and, in some cases, global networks of like-minded entities. These networks are likely to be important in the potential of religious actors to achieve their goals. In sum, what religious state and non-state actors have in common is that they share objectives that, informed by religion, bring a renewed significance of faith issues to IR.

This is all taking place in what has been called a near universal religious resurgence which has emerged since the 1980s. As Casanova (1994: 6) notes, 'What was new and became "news" in the 1980s was the widespread and simultaneous' refusal of religious actors no longer to be restricted to the private sphere. Many religious actors are concerned, not only with narrowly religious or spiritual concerns but also with political, social and/or economic issues which, singly or collectively, challenge both the legitimacy and autonomy of the primary secular spheres: the state, political society and the market economy, in both domestic and international contexts. In doing so, they raise important questions about inter-connections of private and public morality and the claims of both states and markets to be exempt from normative considerations. In general, such concerns were particularly focused by the political, economic, social and cultural impacts of globalisation (Haynes 2005, 2013). In short, many non-state religious actors have appeared in recent years with common aims: seeking to acquire both domestic and international influence, through focus on moral, ethical, economic, social and/or political concerns, and employing various means to achieve their goals.

Within many domestic contexts, religious actors have acquired increased prominence since the 1980s and 1990s. But it took most IR analysts a little longer to accept their significance. 
Reus-Smit notes that in IR religion and culture ${ }^{2}$ were 'largely neglected' until the al Qaeda attacks on the Pentagon and New York's Twin Towers on 9 September 2001 ('9/11').

A consequence of $9 / 11$ and its aftermath was increased focus on ideas in IR including those connected to religion, such as concepts of 'The West' and of 'Islam' as radically different transnational communities. These have been constituted and related to the constitution, or the erosion of state power, and 'can be mobilized to sustain system-transforming political projects, either on the part of liberal democracies, seeking to redefine the norms of sovereignty and global governance, or terrorist organisations seeking an end to the liberal capitalist world order' (Rues-Smit 2005: 211).

The concerns that Reus-Smit points to suggest that when it comes to analysing the impact of religious actors on IR, then it is appropriate to focus upon their ability to wield what Joseph Nye (2004a, 2004b) has called 'soft power'. Before turning to this issue, first I want to focus upon how religion was largely neglected in IR theory until the recent emergence of the 'English School'.

Thomas (2005) argues that religion, in the form of 'religious traditions or movements', can affect IR in three main ways: it can promote or help resolve international conflicts; affect international society's norms, values and institutions; and influence a country's foreign policy. On the first point, the nature of international conflict appears to have changed since the end of the Cold War, with a relative scarcity of interstate wars and growth in numbers of intrastate wars. During the 1990s there were more than 100 major conflicts involving more than 1,000 fatalities each; but only a handful were interstate wars. Most were intrastate conflicts, with over 7 per cent classified as 'communal' wars, characterised by religious and/or ethnic conflict. This suggests that communal issues - that is, those involving religious and/or ethnic concerns - have replaced secular ideologies - such as communism and socialism - as key sources of identity, competition and conflict in IR. The recent eruption of communal conflicts casts serious doubt on the potential to move from the Cold War order - rooted in bipolarity, nuclear deterrence and ideological division - to a post-Cold War configuration characterised by (the pursuit of) peace, prosperity and cooperation.

Religion is often noted as having a key role in both engendering and influencing individual and group values, factors that potentially can affect the formulation and execution of state foreign policies. This is because religion is an important source of basic value orientation both for individuals and for groups of people in developed and developing countries; and this can have social and political connotations. Religion can be 'a mobiliser of masses, a controller of mass action ... an excuse for repression [or] an ideological basis for dissent' (Calvert and Calvert 2001: 140). In sum, consequential to various empirical developments over the last three or four decades, religion has become a focus of analytical attention in both political science and IR, with attention paid to both state and non-state actors.

Second, the relationship between 'international society' - that is, the association of sovereign states based on their common interests, values and norms - and internationally significant non-state religious actors is also a significant issue in this context. Despite being two decades old, Samuel Huntington's $(1993,1996)$ influential analysis still commands attention. Huntington contends that the key post-Cold War threat to international society stems from the threat to the (post-Christian, democratic) 'West' from various forms of 'Islamic extremism'. Huntington's critics, such as Esposito (2002), disagree, arguing that his claims are both overgeneral and lacking strong empirical foundations. This is partly because Islamic extremism 
primarily threatens incumbent domestic rulers and partly because the extremists' interests, values and norms are abhorred by the great majority of 'moderate' Muslims.

Several conclusions follow from these initial statements. First, in recent years, both state and non-state religious actors have become important for understanding international outcomes in many parts of the world. Fundamental norms of IR were enshrined in the Treaty of Westphalia (1648) - particularly the notion of state restraint in religious matters. This encouraged belief that IR discourse is predominantly secular. Second, religion has influenced international outcomes involving international society. Finally, all religious actors' influence in IR is linked to their ability to exercise 'soft power'.

\section{RELIGION AND THEORY IN POST-WESTPHALIAN INTERNATIONAL RELATIONS}

IR theory is based on the premise that historically religion was of central importance to many political outcomes - both within countries and between them - in many parts of the world, including Western Europe. Before the nineteenth century and the development of the 'modern' - that is, increasingly secular - international state system, religion was a key source of political competition and conflict in many parts of the world. Rival religious faiths (notably, intra-Christian, including Protestant/Roman Catholic and Greek Orthodox/Roman Catholic, as well as Christian/Muslim) stimulated, moulded and exacerbated numerous group conflicts in the sixteenth and seventeenth centuries. But following the Peace of Westphalia (1648) and the subsequent development of centralised, secular states - initially in Western Europe and then via colonialism to the rest of the world - the significance of religion for IR declined.

Religion's declining importance for IR was reflected in two international processes - modernisation and secularisation. Both carried a key assumption: sovereign states are the key actors in IR, guided by the secular Westphalian international system, and characterised by a key concept - state sovereignty - and a fundamental principle - non-intervention. These notions gradually became embedded in international thinking in the centuries via institutionalisation of the so-called 'four pillars' of the Westphalian system that reflected the following concerns:

- states are the sole legitimate actor in the international system;

- governments do not seek to change relations between religion and politics in foreign countries;

- religious authorities legitimately exercise few - if any - domestic temporal functions, and even fewer transnationally; and

- there is a separation between church and state, implying that governments do not vigorously promote the welfare of religion(s).

In sum, the Treaty of Westphalia was 'a structure of political authority that was forged centuries ago by a sharply secularizing set of events and that has endured in its secular guise ever since' (Philpott 2002: 79).

The importance of the four pillars is in the fact that a key concern of the Treaty of Westphalia was to remove religion as a justification for war. By the seventeenth century, religious competition and discord had long been at the heart of much European conflict, discord and instability. As the salience of religion for IR declined, it was believed that secular modernisation and the 
rise of science and rationality would combine to put inexorable pressure on religious faith, resulting in its steady decay. This was a shared belief of:

the seminal thinkers of the nineteenth century - Auguste Comte, Herbert Spencer, Emile Durkheim, Max Weber, Karl Marx, and Sigmund Freud - all believed that religion would gradually fade in importance and cease to be significant with the advent of industrial society ... The belief that religion was dying became the conventional wisdom in the social sciences during most of the twentieth century. (Norris and Inglehart 2004: 3)

On the other hand, during the last 20 years, the secularisation thesis has experienced the most sustained challenge in its long history.

At the same time it is noted that only a few governments are significantly motivated by religious considerations in their foreign policy and more generally their IR (Haynes 2013). States have foreign policies that are overtly directed towards achieving a set of national interest goals, interests and aspirations. A state's foreign policy must be flexible enough to follow the changing contours and dynamics of international politics, while simultaneously preserving and promoting national interests. It is widely agreed that any country's domestic environment has a major role in shaping its foreign policy. Foreign policy is to a large extent a reflection of a country's domestic milieu, its needs, priorities, strengths and weaknesses. This suggests that a state's foreign policy is influenced by certain 'objective' conditions - such as history, geography, socio-economic conditions and culture - that interact in complex ways with the changing dynamics of international politics. For a country to enjoy a successful foreign policy it is necessary to achieve a balance between domestic and external dimensions. In sum, foreign policies of all countries are, to some degree, a product of and interaction between (1) a country's overall power indices (including geo-strategic location, economic wealth and health, military strength and domestic political stability) and (2) the prevailing international environment.

How and under what circumstances might religious actors within a country influence its foreign policy, that is, its formulation and execution? It is useful to start from the proposition that as 'religion plays an important role in politics in certain parts of the world' then there will be 'greater prominence of religious organizations in society and politics' in some countries compared to others (Telhami 2004: 71). Table 1.1 posits that the ability of religious actors to translate potential ability into actual influence on foreign policy outcomes will depend crucially on whether such actors can access and thus potentially influence foreign policy decision-making processes and outcomes.

Religious actors' ability to influence foreign policy will depend not only on the nature of a political system's institutional characteristics and the formal opportunities to influence government thinking but also on their ability to wield soft power. For example, the USA has a democratic system that exhibits relatively accessible decision-making structures and processes, potentially offering actors - both individuals and groups - opportunities to influence policy making, both domestic and foreign (Hudson 2005: 295-7). Note, however, that the ability to access decision-making structures and processes does not guarantee religious actors' ability significantly to influence either policy formation or execution. To have a profound policy impact would require them to make often elaborate efforts not only to build coalitions with key political players but also, more generally, to foster good relations with significant players in the political system. These circumstances are likely to be facilitated when, as in the USA after 9/11, there is pronounced ideological empathy between key religious and secular actors. Regarding the former, figures in the religious right can be noted while President George 


\section{Table 1.1 Religious actors and state foreign policies}

\begin{tabular}{|c|c|c|c|c|}
\hline Country & $\begin{array}{l}\text { Type of political } \\
\text { system }\end{array}$ & Majority religion & $\begin{array}{l}\text { Religious actors' access } \\
\text { to foreign policy making }\end{array}$ & Potential impact in case of access \\
\hline India & $\begin{array}{l}\text { Liberal } \\
\text { democracy }\end{array}$ & Hinduism & $\begin{array}{l}\text { Easy - if welcomed } \\
\text { or accepted by policy } \\
\text { makers }\end{array}$ & $\begin{array}{l}\text { Potentially profound - if alliance } \\
\text { forged with state power holders } \\
\text { sympathetic to religious actors' } \\
\text { goals }\end{array}$ \\
\hline Iran & Theocracy & Shia Islam & $\begin{array}{l}\text { Difficult - unless } \\
\text { welcomed by policy } \\
\text { makers }\end{array}$ & $\begin{array}{l}\text { Potentially profound - if alliance } \\
\text { forged with state power holders } \\
\text { sympathetic to religious actors' } \\
\text { goals }\end{array}$ \\
\hline Israel & $\begin{array}{l}\text { Liberal } \\
\text { democracy }\end{array}$ & Judaism & $\begin{array}{l}\text { Easy - if welcomed } \\
\text { or accepted by policy } \\
\text { makers }\end{array}$ & $\begin{array}{l}\text { Potentially profound - if alliance } \\
\text { forged with state power holders } \\
\text { sympathetic to religious actors' } \\
\text { goals }\end{array}$ \\
\hline Saudi Arabia & Theocracy & Sunni Islam & $\begin{array}{l}\text { Very difficult - unless } \\
\text { welcomed by policy } \\
\text { makers }\end{array}$ & $\begin{array}{l}\text { Potentially profound - if alliance } \\
\text { forged with state power holders } \\
\text { sympathetic to religious actors' } \\
\text { goals }\end{array}$ \\
\hline United States & $\begin{array}{l}\text { Liberal } \\
\text { democracy }\end{array}$ & Christianity & $\begin{array}{l}\text { Easy - if welcomed } \\
\text { or accepted by policy } \\
\text { makers }\end{array}$ & $\begin{array}{l}\text { Potentially profound - if alliance } \\
\text { forged with state power holders } \\
\text { sympathetic to religious actors' } \\
\text { goals }\end{array}$ \\
\hline
\end{tabular}

W. Bush and his closest (secular) advisors were key figures in relation to US foreign policy in the Middle East.

Turning to India, another established democracy with similar levels of access to governmental decision makers, we can also note a religious dimension to foreign policy, especially in relation to (Hindu) India's long-running conflict with (Muslim) Pakistan over Kashmir. From the mid-1990s until mid-2004, and then again from 2014, the dominant governing party was the 'Hindu fundamentalist' Bharatiya Janata Party (BJP). To what extent were 'Hindu fundamentalist' characteristics inherent in India's foreign policy during periods of BJP government, especially in relation to its arch enemy, 'Muslim' Pakistan? Ram-Prasad (2000: 188) notes that there was "very little even in a "hard" Hindu nationalism which could translate into an ideology of expansion'. In fact, in India during the period of BJP governments, 'religious ideology in itself has played virtually no direct role in major political and economic decisions', including those related to foreign policy (Ram-Prasad 2000: 153).

We can also note the influence of religious actors in relation to the foreign policies of Saudi Arabia and Iran. First, for decades Saudi foreign policy has been based on ostensibly religious considerations. The Muslim country's government was fervently and consistently opposed both to Jewish Israel and the atheist Soviet Union, while also promoting Islam in various ways around the world. We can see the hand of hard power in operation here: following the onset of oil prosperity in the 1970s, the government donated large sums of money - millions of US dollars annually - to support the spread of Islam in various ways, including the building of mosques and the printing and distribution of numerous copies of the Quran. In addition, Saudi Arabia serves as the chief patron of the Muslim duty to make a pilgrimage to Mecca, expanding arrangements to house and transport the millions of pilgrims who visit Mecca from 
all over the world. Saudi contributions also played a major role in the World Muslim League, a religious propagation agency founded in 1962 with its headquarters in Mecca. Finally, Saudi Arabia is highly influential in the Organisation of Islamic Cooperation, a multinational grouping of Muslim countries that periodically organises summit conferences of government leaders.

We can see the influence of religious soft power in Saudi Arabia's foreign policy, especially a 'purist' strand of Islamism, Wahhabiya. Its influence is reflected in the fact that the country is run as a theocracy, under the aegis of the king, where shariah (Muslim) law is the law of the land and where Islamists have access to the levers of power. At the same time, Saudi Arabia's foreign policy has not only reflected Islam's socio-political dominance. Like every other state, Saudi Arabia has important security goals unconnected to religious objectives. As evidenced by the fear of invasion by Iraq at the time of the first Persian Gulf War in 1990-91 when Iraq invaded Kuwait and seemingly threatened Saudi Arabia, the kingdom's leaders recognise that the country's security is best protected by its alliance with the USA. As a result, Saudi Arabia seeks to balance both religious and secular security goals in its foreign policy. To avoid what might have been unacceptable levels of conflict with the USA, the ruler of Saudi Arabia, King Abdullah, sought to block the support of his rival, Prince Nayef, for al Qaeda and other radical Islamist organisations. Fear of offending Washington also prevented a Saudi/Organisation of Islamic Cooperation stand against US sanctions on Iran and Pakistan for their development of the sole nuclear capacity in the Muslim world. In addition, once Washington began to question Saudi Arabia's strategic loyalty on the basis of its response to 9/11, US attacks on the regime's anti-democratic practices and policies and cultural differences between the two countries suddenly became both apparent and relevant to their relationship.

Iran is a theocracy characterised by the influence of Shia Islam (unlike Saudi Arabia which is a follower of the rival Sunni articulation). Few nations today have so clearly articulated, as has post-revolution Iran, an official religion-based ideology and view of the state as an instrument of that ideology. Iran's foreign policies and activities are not always characterised by a clearly religious dimension, but by a discrepancy between the country's theocratic ideology and policies dictated by its secular security interests. Often propagation of (Shia) Islam and advancing the cause of other Muslim peoples are only minor aspects of Tehran's foreign policy activity.

Whenever the material interests of the state have conflicted with commitments to 'Islamic solidarity', Tehran has almost always given preference to security and economic considerations. Indeed, Iran often uses religion to pursue material state interests - as a way of contending with neighbouring regimes or trying to force changes in their policies. For example, it promotes Islamic radicals and anti-regime movements when official relations with a Muslim country are poor, such as with Uzbekistan or Azerbaijan, but does not work to undermine secular Muslim regimes such as Turkmenistan if that regime's relations with Tehran are good. The Iranian case illustrates the importance of separating a state's rhetoric about its policy decisions from the policies themselves.

Turning to Israel, Chazan (1991: 83) claims that the country's IR and foreign policy are primarily moulded by three domestic factors: '(1) the structure and composition of political institutions; (2) social differentiation and the concern of specific groups; and (3) the substance of political debates and their relations to fundamental ideological concerns'. She adds that 'Israeli responses to external stimuli are filtered through a domestic political lens which operates according to its own distinctive rules' (Chazan 1991: 83; quoted in Ehteshami 2002: 278-9). 
We noted earlier in this chapter that such an arrangement is a common one: foreign policies of all states are affected by domestic political arrangements, including, in some cases, the influence - that is, soft power - of religious actors. In Israel, religious Jews' political significance comes from three main factors: (1) the nature of the country's political system: proportional representation, giving an influential voice to an array of minor parties, including religious ones; (2) society's fragmented nature; and (3) its highly divisive political party system. When we add to this already volatile mix the fact that Israel's public life also reflects the consistently influential voice of public opinion, then it facilitates the conclusion that Israel's foreign policy is heavily affected, but not as we shall see dominated, by the views of religious Jews. Evidence for this conclusion comes from the Sharon government's momentous decision - effected in August 2005 - to remove all 8,000 Jewish settlers from the Gaza Strip, giving some control of it to the Palestinians.

The Gaza Strip was home to 400,000 Palestinians at the time of Israeli occupation in 1967. This presented a great demographic and security problem for the Israelis. Israel's original intention was to annex Gaza and to resettle the Palestinians living there. In 1973 Prime Minister Rabin called for the population to be dispatched to Jordan. While this was not attempted, Jewish settlements grew in number, with the Jewish population growing to about 8,000 people by 2005 . Despite the fact that Gaza's Arab population in the early 1990 s exceeded half a million people - crammed into 140 square miles giving the area a greater population density than Hong Kong - by 1992 the Israelis had confiscated more than a third of the total area and awarded it to Jewish settlers who made up half of 1 per cent of the population. Settlers on average had around 2.6 acres of land each in Gaza, while Palestinians had 0.006 acres each, over 430 times less. But in an effort to increase Israel's security, the government decreed and put into effect a total Israeli pull-out from the Gaza Strip in August 2005. This broke the Israeli state's long-term covenant with the settlers, and made it clear that secular security concerns in Gaza were now more important than the religious goals of the mostly orthodox Jewish settlers. The bond was forged following the 1967 war between secular political leaders and religious Jews, meshing security concerns of the former 'with the visions of a messianic minority to claim the spoils of war as a God-given right' (McGreal 2005). Establishment of Jewish settlements in both the West Bank of the River Jordan and the Gaza Strip served the security interests of successive governments - both Likud and Labor - who saw them as the first line of defence against neighbouring hostile Arab countries. This chimed with the views of religious Jews who believed that the settlements were an important stage on the road to reclamation of all of Eretz Yisrael for the modern Jewish state.

From 2005 the connection between the two was emphatically broken; thousands of Jewish settlers were expelled from their homes in the Gaza Strip, following orders from Prime Minister Ariel Sharon, once their main patron and defender. In removing the settlers from Gaza Sharon it was recognised that the vision of 'greater Israel' was no longer tenable because the country's (secular) security interests no longer aligned with the religious goals of the settlers whose desires had once dominated government decisions.

How do we understand and account for the influence of religious actors on foreign policy in relation to the USA, Israel, India, Saudi Arabia and Iran? These examples underline the fact that in each case it is religious actors' soft power that is most important. It is obviously important for religious actors to get the ear of government through various available mechanisms in order to have a chance of their preferred policies being put into effect. 


\section{THE ENGLISH SCHOOL AND THE CONSEQUENCES OF RELIGION'S INVOLVEMENT IN INTERNATIONAL SOCIETY}

Emerging as an academic discipline after World War I ended in 1918, the discipline of IR initially carried within it a widespread belief that religion was of little or no analytical importance. It was afforded little attention or emphasis, especially in the USA, where the main secular interpretations of IR - especially Realism - were prominent. In the USA, study of IR was widely informed by two assumptions. First, rationality and secularity go hand in hand. Second, trouble-free functioning of 'modern' political, economic and social systems - not only in the USA but by extension elsewhere - depends upon a clear separation of religion and politics, reflected in the USA's constitutional division between 'church' and 'state'.

In Britain, the other centre of IR enquiry, IR theory took a different turn, especially after World War II ended in 1945. This was reflected in the emergence, in the 1950s, of a focus in IR analysis known as the 'English School'. It is so named because its major figures, although often not English, did work in English universities (including the London School of Economics and Political Science, as well as at Oxford and Cambridge) during its formative years. Key scholars linked to the English School include: Martin Wight, Hedley Bull, R.J. Vincent, James Mayall, Robert Jackson, Tim Dunne and Nicholas J. Wheeler.

According to Barry Buzan (2004: 6), one of its leading proponents, 'The English School can be thought of as an established body of both theoretical and empirical work.' What primarily distinguishes the English School is its concern with morality and culture, leading to a distinctive approach to the study of IR that highlights issues of coexistence and cooperation, as well as conflict, especially in the relations between sovereign states. The English School's main concern is with the evolution of what is called 'international society' (Brown 2005: 51). Jackson and Owens (2005: 46) define international society as involving:

relations between politically organized human groupings, which occupy distinctive territories and enjoy and exercise a measure of independence from each other. International society can thus be conceived as a society of political communities that are not under any higher juridical political authority. In the language of international relations these communities are referred to as states.

Hedley Bull, one of the founders of the 'international society' approach, avers that the 'starting point of international relations is the existence of states, or independent political communities, each of which possesses a government and asserts sovereignty in relation to a particular portion of the earth's surface and a particular segment of the human population (Bull 1977: 8). Thus for Bull, the main focus of the study of IR is the 'world of states' not sub-state entities or universal categories, such as 'humanity' (Brown 2005: 51). According to the ideas of the English School, when states interact they do not merely form an international system but an international society, involving a "norm-governed relationship whose members accept that they have at least limited responsibilities towards one another and to the society as a whole. These responsibilities are summarised in the traditional practices of international law and diplomacy' (Brown 2005: 51).

The resurgence of religion in IR raises a theoretical issue: the possibility of an international society in a multicultural international system (Zacher and Matthew 1995). We noted earlier that Huntington controversially raised this issue when asking whether a 'clash of civilisations' has replaced the secular ideological confrontation of the Cold War as the main axis of division in world politics. Benjamin Barber (1992) argues that the principle axis of world politics is 
'Jihad vs. McWorld', that is, the forces of particular religious 'tribalisms' and the universal, economic, ecological and commercial forces of 'globalism'. Many analysts in the US foreign policy community believe Islamic fundamentalism has replaced communism as the main threat facing the USA. The explicit linkage between - it should be said - non-Western religious nationalism and a type of 'new cold war' facing the West is made by Juergensmeyer (1993). Former North Atlantic Treaty Organization (NATO) secretary-general Willy Claes stated in the mid-1990s that Islamic fundamentalism poses just as much a threat to the West as did communism during the Cold War: 'NATO is much more than a military alliance. It has committed itself to defending basic principles of civilisation that bind North America and Western Europe' (The Guardian 1995). In sum, the consequence of religion for international society is not only a theoretical problem in IR but it can also be a practical foreign policy problem, as evidenced by the events and aftermath of $9 / 11$, as well as, more recently, the depredations of 'Islamic State' and the perplexed Western response.

How the relationship between religion and international society is approached may be influenced by our understanding of how the current global international society came about. Barry Buzan (2004), in an attempt to relate structural realism and regime theory to the concept of international society (using F. Tönnies' terms), develops the idea of a gemeinschaft understanding of society, which sees society as something organic, and traditional, involving bonds of common sentiment, experience and identity; and a gesellschaft understanding of society, which sees society as being contractual and constructed rather than sentimental and traditional.

Members of the English School assume a degree of cultural unity among the members of international society, in which the units (i.e. states) share significant elements of culture, especially religion and language, and 'since a prior shared culture occurs in most of the main historical examples ... the force of the argument is strong' (Buzan 1993: 333). Buzan points to the 'messy multicultural history of the Middle East' to suggest that significant elements of international society can form a sub-system that does not share a common culture. 'This points to a functional view, more in accordance with a gesellschaft understanding of society, in which the development of international society can be seen as a rational long-term response to the existence of an increasingly dense and interactive international system' (1993: 334). The point is that whether or not states share a common culture, at some point the regularity and intensity of their interactions will force the development of a degree of recognition and accommodation between them, and they will work out rules for avoiding unwanted conflict and for facilitating desired changes. In other words, international society can evolve functionally from the logic of anarchy without pre-existing cultural bonds.

Hedley Bull (1977: 4-5) accepts this functional, gesellschaft view of international society in his minimum conditions for international order: (1) limits on the use of force, (2) sanctity of contracts (including treaties), and (3) arrangement for property rights. The issue of property rights may be more problematic, but for the first two conditions - the use of force and treaties - an important question emerges: is there a universality of these basic conditions which the main religious traditions uphold in their respective societies in spite of the cultural differences between them? Religions and cultures differ but might they still have principles that are common or universal? If this is so, we might be exaggerating the impact of religious or cultural differences on world politics because of the common, underlying principles on which international society is based. On some (limited) issues there are common principles that underlie different cultures, for example, principles regarding the use of force and respect for treaties, which are upheld by their respective religious traditions. There are also other issues, such as 
human rights and the role of women in society, on which the dialogue within these societies continues. This is what Said (1995) calls the 'battle within civilisations' (my emphasis), and he suggests this is what animates politics in much of the developing world, pace Huntington, not primarily a clash between civilisations.

This chapter is agnostic on whether a morality beyond culture exists. What it does suggest is that the internal debate or dialogue on the relationship between religion and modernity is not a new debate; it has been going on in different societies since the days of colonialism and imperialism. There is no 'original position' of inter-cultural ignorance, as multiculturalists might have us believe, in which Asia, for example, has been hermetically sealed off from the West until now, has a 'different standard' of human rights, and the West another standard, and these standards are now coming into conflict for the first time. The great world religions - such as Islam, Confucianism, Hinduism and Christianity - may have fixed texts but they do not have fixed beliefs, only fixed interpretations of those beliefs. Religions can be called transnational ideas or ideational communities, but what is most important about them is that they are interpretive communities, in dialogue with their members and with society on the contemporary significance of each tradition.

This fact is troubling for IR theory which is far more comfortable with the idea of states as key actors. This also implies that hermeneutics cannot be separated from politics, domestic or international. For example, the recent rise of East Asian economies, and the growing power of such countries - including, China, South Korea and Vietnam - is what has led to a reconsideration of Confucianism and its relationship to economic growth. Growing Asian economic power is what is behind the international debate on human rights and to an extent the associated discussion about the role of religion in IR theory.

How does the concept of international society engage with the notion of multicultural IR? A starting point is to note that it makes sense to think of the idea of international society as 'an occasionally idealized conceptualisation of the norms of the old, pre-1914 European states system'. If this is right, a good question would be whether 'international society' provides a satisfactory starting point for understanding our contemporary world order, where the majority of states are non-European. It is at least arguable that the old order worked as well as it did because there was quite a high level of cultural homogeneity in the system; Europeans shared a common history, albeit one of frequently violent relationships, and common Graeco-Roman cultural origins. Even so the divide between (Greek) Orthodox and (Roman) Catholic Europe was a source of some tension, as had been, in the sixteenth and seventeenth centuries, the divide in the West between Protestant and Catholic Europe. How much more problematic would the normative basis for an international society be, composed, as today it must be, of states based in many cultures - Islamic, Hindu, Confucian and African as well as 'Western' (Brown 2005: 51)?

As the twenty-first century dawned, the significance of cultural explanations appeared to be reaffirmed amid the reorganization of world politics that followed the end of the Cold War and the release of new waves of globalization. And, as Brown (2005: 48) notes, 'theorists of globalization reject the state-centrism involved in [many IR approaches] in favour of an approach that stresses global social, economic, cultural and political forces'. This encourages us to engage with the issue of what might be called 'cultural globalisation' as a central facet of globalisation more generally. This issue also highlights the hitherto Eurocentric nature of IR theory and suggests that to understand religion in IR theory more generally, we need to bear in mind that the intrusion of new global actors into IR implies that our theories to under- 
stand IR need to change too. Much early theorising about globalisation focused on cultural changes stimulated by the global spread of identical consumer goods and an American(ised) culture. Disseminated primarily by US-based transnational corporations to Latin America and elsewhere, cultural Americanisation subverts local cultures, not only encouraging people to become 'consumers' above all else but also to buy US goods and services to the detriment of those produced locally. Together, the 'media revolution' characteristic of post-Cold War globalisation and the growth of consumerism help swiftly to erode particularistic cultures and values, replacing them with an Americanised 'global culture' of Disney, McDonald's, Coca-Cola and Starbucks.

Saurin (1995: 256) argues that culture has become a potent political force threatening the basis of the current fragmented state system and its structures of supporting nationalism. This is because, he argues, 'culture avoids being located and tied down to any definable physical space'. However, and somewhat paradoxically, nationalism and ethnic awareness are also cultural components transmitted around the globe, becoming both a globalised and a globalising phenomenon. One of the main causes of contemporary ethnic and religious conflict in many countries is said to be such groups' awareness of what other groups around the world are doing, and with this knowledge seeking to emulate counterparts' struggles for greater power.

A further result of the spread around much of the world of Americanised culture and ideas is a growing adherence to its key component: individualistic, as opposed to communal, values. This development is apparent in the global clamour for more and better (individualistic) human rights. While 'anti-American' entities, such as Islamic extremists and some Asian governments, including that of China, fight this development, there is no denying that human rights issues are now widely perceived as worldwide problems, necessitating global solutions. This has stimulated the development of international organisations and global institutions which attempt to address such issues. More tentatively, the concept also suggests the development of a transnational civil society, in which local groups and grassroots organisations from all parts of the world interact (Haynes 2012).

The revival of what is termed 'identity politics' has not simply rested on ethnicity and nationalism, and neither has it been confined to Europe or Eurasia. A striking feature of the last two or three decades has been the increasing number of people who have adopted a political identity based on religion and, especially, on 'fundamentalist' religious ideas and movements. Identity matters, and in IR theory constructivism has done Middle East studies a service in providing an influential theoretical approach to understand international outcomes in the region. On the other hand, constructivist accounts often overlook the material context of identity and, as a result, are as mistaken as materialist attempts to reduce it to only a minor issue. This is because material and normative variables are autonomous, while a steady social order depends on a relative correspondence between them.

When norms do not correspond to material structures, the former lack the material anchor to endure and the latter the legitimacy to survive without the continual application of coercive power. Arguably, the main source of the enduring instability of the Middle East is the continuing contradiction between externally imposed structures (the fragmenting states system, the region's international dependency) and the region's Arab and Islamic identities ... Understanding this dynamic requires a theoretical approach that charts the interaction of material structures and norms, of interests and identity, and this requires bridging the constructivist-utilitarian gap. One commonly proposed compromise is to use constructivist methods in a first step to trace how domestic identity shapes states' conceptions of their interests; thus rather than a priori defining interests as wealth and power, Arab nationalism 
and Islam could be shown to shape a notion of interest putting a high value on regional autonomy. (Hinnebusch 2005: 170)

In sum, associated with metaphors like 'the hollowed-out state' and 'a borderless world', globalisation is a focal point of changing economic, political and cultural arrangements and configurations within countries. The result is erosion of the nation-state's formerly 'hard' boundaries and a diminution of states' ability to control their domestic environments. This implies that globalisation reduces the power of the nation-state to make definitive decisions regarding its own future. On the other hand, this 'globalisation thesis' is at odds with several traditional, embedded assumptions of political analysis. These include an understanding that the world comprises: (1) confined political territories governed by national - sovereign - states, (2) nation-states and (3) national economies. These have long been regarded, respectively, as the 'natural' units of political and political economic analysis. The globalisation thesis implies that these long-standing arrangements are in the process of being transcended.

Rejection of state-centric IR highlights the significance both of various kinds of non-state actors as well as transnational networks for international outcomes. Many students of IR have long been cognisant of the argument that the 'nation-state is in retreat'. In the late 1960s and 1970 s, a primary debate in the field of IR was about the status of the state in the international system. The key question was: 'Is the state obsolete?' Coming up with no clear, definitive answer, this turned out to be a recurring question. On the one hand, there was the state-centric (or billiard ball) model of the international system while, on the other, what was known as the 'cobweb' model was informed by the idea that the state was being tied down and increasingly incapacitated by the growth of countless transnational connections. Later, in the 1980s, the state made a comeback. Most IR specialists accepted (once again) that it still represented the most significant actor by far in the international system. Later, in the 1990s, as globalisation entered the conceptual fray, IR, like other social sciences, was encouraged, once again, to survey the putative extinction of the nation-state.

\section{RELIGIOUS ACTORS, INTERNATIONAL RELATIONS AND 'SOFT POWER'}

Although many authors attest to the current significance of religion in IR - with some observers noting a recent widespread religious resurgence (Fox and Sandler 2004; Haynes 2012, 2013; Hoeber Rudolph 2005; Micklethwait and Wooldridge 2009; Norris and Inglehart 2004; Thomas 2005) - there have been few recent attempts to seek to assess how transnational religious actors affect IR. This is surprising given the widespread agreement that such actors can be influential. For example, the numerous extant cross-border Islamic movements all have soft power that enhances their strength (Voll 2008: 262-6). However, as Fox and Sandler (2004: 168) note, religion can also affect international outcomes via 'its significant influence on domestic politics. It is a motivating force that guides many policy makers.' This is a way of saying that some countries may well use religion as an instrumental component of their foreign policies. As we shall see, this is what the current government of Iran does in relation to its relations with Iraq, seeking to use existing Shia networks to increase its influence.

The concept of 'soft power' refers to means to achieve objectives. It 'is the ability to get what you want through attraction rather than coercion or payments. It arises from the attrac- 
tiveness of a country's culture, political ideals, and policies. When our policies are seen as legitimate in the eyes of others, our soft power is enhanced' (Nye 2004a). When Joseph Nye (1990) introduced the concept into IR two decades ago, it was a useful reminder that hard power is not the only tool available to achieve goals. Power is the ability to influence others to get them to do what you want. There are three main ways to do this: (1) threaten them with sticks; (2) pay them with carrots; and (3) attract them or co-opt them, so that they want what you want. As Nye (2004b) points out, if you can get others to be attracted, to want what you want, it costs you much less in both carrots and sticks.

Nye's main focus is the rise and fall of US soft power. After World War II, US political ideals favourably influenced Europe in the direction of both democratisation and market economies. During the Cold War, Radio Free Europe helped to build support for both democracy and improved human rights in communist Central and Eastern Europe. In 1989, Chinese students demonstrating in Tiananmen Square used a replica of the Statue of Liberty as a symbol. In 2010, satellite television helped build support in Iran for Western political and economic ideals. As Nye notes:

These are all examples of America's soft power. When you can get others to admire your ideals and to want what you want, you do not have to spend as much on sticks and carrots to move them in your direction. Seduction is always more effective than coercion, and many values like democracy and human rights, and individual opportunities are deeply seductive. As General Wesley Clark put it, soft power 'gave us an influence far beyond the hard edge of traditional balance-of-power politics.' But attraction can turn to repulsion if we act in an arrogant manner and destroy the real message of our deeper values. (www.futurecasts.com/book\%20review\%206-4.htm)

'Soft power' refers to the capability of an entity, usually but not necessarily a state, to influence what others do through persuasion, not force or threats. Soft power attracts or co-opts people; it does not coerce them. Soft power influences people by appealing to them, not by forcing them to comply. Soft power covers certain attributes - including, culture, values, and ideas - collectively representing different, but not necessarily lesser, forms of influence compared to 'hard' power. The latter implies more direct, forceful measures typically involving the threat or use of armed force or economic coercion. In short, soft power is neither 'sticks nor carrots' but a 'third way' of achieving objectives. It goes beyond simple influence - that can rest on hard power threats both military or diplomatic as well as financial payments - to involve persuasion and encouragement rooted in shared norms, values and beliefs. Exercising soft power relies on (1) persuasion, or the ability to convince by argument, and on (2) the ability to attract.

If I am persuaded to go along with your purposes without any explicit threat or exchange taking place - in short, if my behavior is determined by an observable but intangible attraction - soft power is at work. Soft power uses a different type of currency - not force, not money - to engender cooperation. It uses an attraction to shared values, and the justness and duty of contributing to the achievement of those values. (Nye 2004c, italics added)

In sum, whereas hard power - military or economic influence, involving overt leverage and/ or coercion - is the ability to force people to do things, irrespective of whether or not they agree with them, soft power moulds preferences to encourage people to want to do things. In other words, soft power is the power of attractive ideas, capable of persuading people to act in a certain way. 
Today, it is possible to talk about transnational religious soft power, although the concept is not new. For example, Christian and Muslim religious missions have for centuries been key expressions of transnational religious soft power. Their aim was and is to seek to change people's religious norms, values and beliefs from one set of views to another set. The result is that individuals and then communities in foreign countries eventually behave religiously like the original proselytisers. As Nye notes, 'for centuries, organized religious movements have possessed soft power' (Nye 2004a: 98). In recent years, especially since 9/11, competing conceptions of soft power have competed with each other, within the context of the 'war on terror'. The USA has sought to project its soft power but has not been able to convince most Muslims that US objectives in Afghanistan and Iraq are not primarily self-serving (Shlapentokh et al. 2005). The USA has found itself competing for Muslim hearts and minds with both 'extremist' and 'moderate' Islamic soft power.

Focusing on both extremist and moderate Islamic transnational networks, many analysts agree that extremist movements - notably al Qaeda - more strongly affect the world stage and receive more foreign policy attention from the great powers than many 'weak' states in the international system (Haynes 2005; Voll 2008). Of course, the relevant literature does not begin and end with Islam. Other religious entities - including the Roman Catholic Church, Protestant evangelical churches (often conservative and USA-based or rooted) and Jewish lobbies - are also significant transnational religious actors at the current time (Norris and Inglehart 2004; Thomas 2005; Voll 2006; Walt and Mearsheimer 2006). What they all have in common is significant amounts of soft power, which encourage followers and those sympathetic to their goals to adopt norms, values and beliefs that encourage them to act in certain ways and not others.

Religious soft power expands the use of the term 'soft power' beyond Nye's original argument. Initially, soft power was the influence one government exercises over another to try to achieve its goals. Over time, however, Nye accepts the plausibility of a non-state actor having soft power. For example, commenting on Hezbollah's war with Israel in early 2009, Nye makes it plain that the concept of soft power can include non-state cultural and religious actors who seek to influence policy by encouraging policymakers to incorporate into their policies religious beliefs, norms and values. For example:

Israel used its hard military power in a manner that bolstered Hezbollah's soft power and legitimacy in Arab eyes, including many Sunnis who were originally skeptical of a Shi'ite organization with ties to non-Arab Iran. We know that terrorist organizations most often lose popular support by their own excesses - witness the drop among Jordanians in the soft power of Al Qaeda in Iraq, led by Abu Musab al-Zarqawi, after the organization bombed a wedding in an Amman hotel. (http://theinnercircle .wordpress.com/2009/07/15/joseph-s-nye-jr-s-explanation-of-smart-power-in-the-middle-east/)

In sum, whatever their objectives, transnational religious actors aim to spread influence by the establishment and development of cross-border networks. They seek to do this through the application and development of 'transnational religious soft power'. They must seek to use soft power because such actors very rarely have any hard power worth speaking of. Extending the meaning of the term soft power in this way allows us to include transnational religious actors, such as the Roman Catholic Church and al Qaeda, who have sought to apply soft power, aiming to encourage significant religious and political changes in, for example, Poland or Yemen. 
A theory of IR - known as liberal internationalism - takes into account these transnational advocacy networks in seeking to explain outcomes in IR. Liberal internationalism is based on four key premises:

- International stability and order require building and upholding appropriately consensual international institutions and norms.

- Building and sustaining relevant international institutions and norms are core aspects of an international society aiming to bring 'peace and prosperity to all'.

- To achieve this goal, it is necessary to discover, cultivate and implement shared values that help achieve this aim.

- States are no longer automatically the primary actor in world politics in every context and in relation to every issue (Burchill 2005: 64-6).

A theoretical approach in IR - the liberal internationalist view - notes several distinct forms of influence, with Keohane and Nye's (1977) typology of world politics as 'complex interdependence' often the starting point. This is a 'multiple issues' agenda encouraging government decision makers - once concerned 'only' with 'domestic' issues, for example, energy, telecommunications, food, agriculture and the natural environmental - to take external actors into account. This not only presents organisational difficulties in coordinating the work of different branches of government but also 'generates political problems as a proliferation of newly created policy coalitions seek to influence policy' (Webber and Smith 2002: 63-4). In short, there are now multiple channels of contact linking states and societies, both within and between countries, and in some cases this includes various religious actors that may impact upon both policy-making and execution through their ability to wield soft power. Overall, liberal internationalists recognise the potential and in some cases actual importance of religious actors in IR, in relation to specific issues and outcomes. Such analyses also recognise the ability of soft power under certain circumstances to be influential in relation to international outcomes.

The number of transnational non-state actors grew from a few thousand 30 years ago to an estimated 25,000 'active' organisations in the early 2000s and more than 40,000 today (Haynes 2015). While many are secular in orientation a large number are religious. Collectively, transnational religious networks can be influential motivators of, as well as participants in, conflict; they can also be independently significant in promoting various normatively 'progressive' objectives, including: peace, inter-group understanding, cooperation and human development.

\section{OVERALL CONCLUSION}

In terms of state-related religious power, our examples - the USA, India, Saudi Arabia and Iran - collectively underline 'that religion's greatest influence on the international system is through its significant influence on domestic politics. It is a motivating force that guides many policy makers' (Fox and Sandler 2004: 168). To understand and account for the influence of religious actors on foreign policy in relation to the USA, India, Saudi Arabia and Iran, we saw that their wielding of soft power is the best - actually, the only - way to influence foreign policy. We also learnt that while it is obviously important for religious actors directly to get the ear of government through various available mechanisms - both formal and informal - in order to have a chance of their preferred policies being put into effect, there are also additional 
means, including trying to mould public opinion through the media, demonstrations or via think tanks, that might be used. In sum, religious actors may try to influence outcomes in IR by encouraging states to adopt foreign policies that they believe are most in tune with their religious values and goals. We shall examine this issue further in later chapters.

We also saw that there is another category of religious actors - non-state religious actors - who attempt to influence IR through a focus on transnational civil society. Transnational religious networks have received growing attention since the end of the Cold War in 1989, but the ability of such actors to influence outcomes in IR is variable.

In sum, we saw in this chapter that both state-related and non-state religious actors can be of significance for outcomes in IR. Overall, four main points were made in the chapter:

- State foreign policies can be motivated or significantly influenced by religious actors.

- Domestic religious actors can cross state borders and become internationally significant.

- Various strategies are used in these transnational religious phenomena to try to achieve their goals.

- Religious norms and values can affect IR in various ways, which in turn affect how we create and use IR theories involving 'religion' and 'culture'.

\section{NOTES}

1. On the issue of ideas in IR relating to religion and secularisation, see Philpott (2000: 217ff).

2. Reus-Smit (2005: 211) defines culture as a broad 'framework on inter-subjective meanings and practices that give a society a distinctive character'.

\section{REFERENCES}

Barber, B. (1992) 'Jihad vs. McWorld', The Atlantic Monthly, March.

Brown, C. (2005) Understanding International Relations, 3rd ed., Basingstoke: Palgrave.

Bull, H. (1977) The Anarchical Society, London: Macmillan.

Burchill, S. (2005) 'Liberalism', in S. Burchill, A. Linklater, R. Devetak, J. Donnelly, M. Paterson, C. Reus-Smit and J. True (eds), Theories of International Relations, 3rd ed., Basingstoke: Palgrave, pp. $55-82$.

Buzan, B. (1993) 'From international system to international society: Structural realism and regime theory meet the English School', International Organization, 47, 3 (Summer), pp. 327-52.

Buzan, B. (2004) From International to World Society? English School Theory and the Social Structure of Globalisation, Cambridge: Cambridge University Press.

Calvert, P. and Calvert, S. (2001) Politics and Society in the Developing World, London: Routledge.

Casanova, J. (1994) Public Religions in the Modern World, Chicago, IL: University of Chicago Press.

Chazan, N. (1991) 'The domestic foundations of Israeli foreign policy', in J. Kipper and H. Saunders (eds), The Middle East in Global Perspective, Boulder, CO: Westview.

Ehteshami, A. (2002) 'The Middle East: Iran and Israel', in M. Webber and M. Smith (eds), Foreign Policy in a Transformed World, Harlow: Prentice Hall, pp. 255-86.

Esposito, J. (2002) Unholy War, New York: Oxford University Press.

Fox, J. and Sandler, S. (2004) Bringing Religion into International Relations, Basingstoke: Palgrave Macmillan.

Hay, C. (2002) 'Globalisation, "EU-isation" and the space for social democratic alternatives: Pessimism of the intellect: A reply to Coates', British Journal of International Relations, 4, 3 (October), pp. 452-64.

Haynes, J. (2005) Comparative Politics in a Globalizing World, Cambridge: Polity. 
Haynes, J. (2012) Religious Transnational Actors and Soft Power, Aldershot: Ashgate.

Haynes, J. (2013) An Introduction to International Relations and Religion, London: Pearson.

Haynes, J. (2015) Faith-Based Organizations at the United Nations, New York: Palgrave Macmillan.

Hinnebusch, R. (2005) 'The politics of identity in Middle East international relations', in L. Fawcett (ed.), International Relations of the Middle East, Oxford: Oxford University Press, pp. 151-72.

Hoeber Rudolph, S. (2005) 'Religious transnationalism', in M. Juergensmeyer (ed.), Religion in Global Civil Society, New York: Oxford University Press.

Hudson, M. (2005) 'The Unites States in the Middle East', in L. Fawcett (ed.), International Relations of the Middle East, Oxford: Oxford University Press, pp. 283-306.

Huntington, S. (1993) 'The clash of civilisations?', Foreign Affairs, 72, 3, pp. $22-49$.

Huntington, S. (1996) The Clash of Civilizations, New York: Simon and Schuster.

Jackson, R. and Owens, P. (2005) 'The evolution of international society', in J. Baylis and S. Smith (eds), The Globalization of World Politics, 3rd ed., Oxford: Oxford University Press, pp. 45-62.

Juergensmeyer, M. (1993) The New Cold War? Religious Nationalism Confronts the Secular State, Berkeley, CA: University of California Press.

Keohane, R. and Nye, J. (1977) Power and Interdependence: World Politics in Transition, Boston, MA: Little Brown.

McGreal, C. (2005) 'Sharon breaks covenant with settlers', The Guardian, 18 August.

Micklethwait, J. and Wooldridge, A. (2009) God Is Back: How the Global Rise of Faith Is Changing the World, Harmondsworth: Penguin.

Norris, P. and Inglehart, R. (2004) Sacred and Secular: Religion and Politics Worldwide, Cambridge: Cambridge University Press.

Nye, J. (1990) Bound to Lead: The Changing Nature of American Power, New York: Basic Books.

Nye, J. (2004a) Soft Power: The Means to Success in World Politics, Washington, DC: Public Affairs.

Nye, J. (2004b) 'Soft power: The means to success in world politics', Carnegie Council. Available at: www.carnegiecouncil.org/resources/transcripts/4466.html. Last accessed 1 May 2012.

Nye, R. (2004c) 'The benefits of soft power', Harvard Business School Working Knowledge, 2 August. Available at: http://hbswk.hbs.edu/item.jhtml?id=4290\&t=globalization. Last accessed 10 April 2006.

Philpott, D. (2000) 'The religious roots of modern international relations', World Politics, 52, pp. 206-45.

Philpott, D. (2002) 'The challenge of September 11 to secularism in international relations', World Politics, 55, October, pp. 66-95.

Ram-Prasad, C. (2000) 'Hindu nationalism and the international relations of India', in K. Dark (ed.) Religion and International Relations, Basingstoke: Macmillan, pp. 180-98.

Rues-Smit, C. (2005) 'Liberal hierarchy and the license to use force', Review of International Studies, 31, December, pp. 209-21.

Sahliyeh, E. (1990) 'Introduction', in E. Sahliyeh (ed.), Religious Resurgence and Politics in the Contemporary World, Albany, NY: State University of New York Press, pp. 1-20.

Said, E. (1995) Orientalism: Western Conceptions of the Orient, London: Penguin Books.

Saurin, J. (1995) 'The end of international relations?', in J. Macmillan and A. Linklater (eds), Boundaries in Question: New Directions in International Relations, London: Pinter, pp. 244-61.

Shlapentokh, V., Woods, J. and Shiraev, E. (eds) (2005) America: Sovereign Defender or Cowboy Nation?, Aldershot: Ashgate.

Telhami, S. (2004) 'Between faith and ethics', in J.B. Hehir, M. Walzer, L. Richardson, S. Telhami, C. Krauthammer and J. Lindsay (eds), Liberty and Power: A Dialogue on Religion and US Foreign Policy in an Unjust World, Washington, DC: Brookings Institution Press, pp. 71-84.

The Guardian (1995) 'Private morals', 27 March.

Thomas, S. (2005) The Global Transformation of Religion and the Transformation of International Relations: The Struggle for the Soul of the Twenty-First Century, New York: Palgrave Macmillan.

Voll, J. (2006) 'Trans-state Muslim movements in an era of soft power', Paper prepared for the Conference on New Religious Pluralism in World Politics, Georgetown University, 17 March.

Voll, J. (2008) 'Trans-state Muslim movements and militant extremists in an era of soft power', in T. Banchoff(ed.), Religious Pluralism, Globalization, and World Politics, New York: Oxford University Press, pp. 253-74.

Walt, S. and Mearsheimer, J.J. (2006) 'The Israeli lobby and US foreign policy', London Review of Books, 23 March. 
Webber, M. and Smith, M. (2002) Foreign Policy in a Transformed World, Harlow: Prentice Hall.

Zacher, M. and Matthew, R. (1995) 'Liberal international theory: Common threads, divergent strands', in C. Kegley (ed.), Controversies in International Relations Theory, New York: St Martin's Press, pp. 107-50. 